\title{
Dietary studies of toothed whales: A review of technical issues and new topics
}

\author{
HIROSHI OHIZUMI \\ Japan Science and Technology Corporation / National Research Institute of Far Seas Fisheries, Shimizu, \\ Shizuoka 424-8633, Japan (ohizumi@affrc.go.jp)
}

SUMMARY: Understanding the feeding habits of toothed whales is important in studies of cetacean ecology. The techniques of stomach content analysis have become more refined, and it is now possible to identify a lots of fishes and cephalopods using hard parts such as otoliths and beaks. These hard parts can also provide estimations of the body sizes of several hundred prey species. The prey selectivity of toothed whales has been summarily dismissed as being "opportunistic" and there has been little discussion about the mechanisms of prey switching. Recent detailed information on prey items has enabled researchers to consider prey selectivity when data of prey abundance are available. The detection of selection criteria may be an interesting topic in future studies concerning behavioral ecology. The ecological importance of cetaceans has been considered recently, and their prey consumption has been discussed as a matter of concern about competition with fisheries. Some toothed whales in coastal areas consume many prey species that are commercially caught. However, the competitive status may not only depend on the overlapping of prey, but also on the prey abundance and the ecological response of prey to predation and harvesting pressures.

\section{KEYWORDS: beak, food consumption, otolith, prey selection, stomach contents, toothed whale}

\section{INTRODUCTION}

Understanding the feeding habits of toothed whales is important in studies of cetacean ecology. Researchers can obtain detailed information about food and feeding habits by analyzing stomach contents. Recently, the trophic importance of cetaceans in the marine ecosystem has been regarded. Information on the diet and prey consumption of cetaceans has sparked interest not only from a purely academic viewpoint but also as a concern to fisheries management. This paper reviews some technical issues in stomach content analyses, as well as several new topics, and considers the current status of dietary studies of toothed whales and problems in those studies.

\section{PREY SPECIES IDENTIFICATION AND SIZE ESTIMATION}

Hard parts of prey, such as fish otoliths and squid beaks, are resistant to digestion. The morphology of these hard parts was first systematically used for identification of prey species in the stomach contents of toothed whales during the 1960 s. Scientists were able to identify even digested prey and could estimate the number of prey items ingested. This method for identification requires many reference samples covering a variety of potential prey species. The key characteristics in the otoliths and beaks of each species must be identified prior to the analysis. These two points are potential barriers to stomach content analysis, but published information is becoming increasingly available (Table 1 ). In addition to otoliths, some other bones are also useful for fish identification. Otoliths have a heavier specific gravity and are easier to collect than other bones from a mixture of stomach contents. Additional bones are useful, however, for species whose otoliths are very small.

The number of prey items found in stomach contents may be overestimated when the estimate is based on the number of hard parts detected. This may be a result of the accumulation of hard parts over time, and it may be a result of misidentifying "prey of prey". A typical expected case of "prey of prey" would occur in species that feed on ommastrephid squids, which in turn prey heavily on myctophids. However, myctophid otoliths comprised $<1 \%$ of prey items found in the stomach contents of northern form short-finned pilot whales (Globicephala macrorhynchus) that feed mainly on ommastrephid squids (Ohizumi H. \& Isoda T., unpubl. data). Thus, "prey of prey" may not have a substantial impact on estimates of stomach contents. Japanese common squids (Todarodes pacificus) often discard the heads of fishes. This reduces the number of "prey of prey" otoliths. On the other hand, accumulation may cause errors in estimates of the daily ration, or feeding rate.

For some species, prey sizes can be allometrically estimated from the sizes of otoliths or beaks (Table 1). However, Tollit et. al. ${ }^{1)}$ noted that otoliths in the feces of pinnipeds were up to $30 \%$ smaller than their original sizes. This problem may be avoided in the analyses of 
Table 1. Published references of otolith and beak.

\begin{tabular}{|c|c|c|c|c|c|c|}
\hline \multirow{2}{*}{ Reference } & \multirow{2}{*}{ Parts } & \multirow{2}{*}{$\begin{array}{l}\text { No. of } \\
\text { species }\end{array}$} & \multirow{2}{*}{$\begin{array}{l}\text { No. of } \\
\text { family }\end{array}$} & \multicolumn{2}{|c|}{ No. of regression (sp.) } & \multirow{2}{*}{ Area } \\
\hline & & & & Body length & Body weight & \\
\hline \multicolumn{7}{|l|}{ Fish } \\
\hline Ohe ${ }^{15)}$ & Otolith & 415 & 124 & $=$ & - & Japan \\
\hline Smale et. al. 16) & Otolith & 972 & 181 & 203 & 193 & South Africa \\
\hline Rivaton and Bourret 17) & Otolith & 998 & 162 & - & - & Western South Pacific-Indo Ocean \\
\hline Harvey et. al. 18) & Otolith & 76 & 24 & $62(46)^{*}$ & 60 & Eastern North Pacific \\
\hline Ohizumi et. al. 19) & Otolith & 36 & 1 & 17 & 18 & Western North Pacific \\
\hline Hotta 20) & Skull, Vertebrae & 266 & 106 & - & - & Japan \\
\hline Takahashi 21) & Skull, Vertebrae & 256 & 100 & - & - & Inland Sea, Japan \\
\hline Tatara et. al. 22) & Vertebrae & - & - & 74 & 74 & Inland Sea, Japan \\
\hline Wattet. al. 23) & Premaxillae, Vertebrae & 51 & 16 & 31 & - & North Sea \\
\hline \multicolumn{7}{|l|}{ Cephalopod } \\
\hline Hotta 24) & Lower beak & 21 & 9 & - & - & Japan \\
\hline Wolff 25 ) & Lower, upper beak & 19 & 8 & 18 & 18 & Pacific Ocean \\
\hline Clarke 26) & Lower beak & ca. 207 & 40 & $60^{* *}$ & $68^{* *}$ & World ocean \\
\hline Kubodera et. al. 27) & Lower beak & so & 19 & - & - & Western North Pacific \\
\hline
\end{tabular}

* 62 original and 46 cited regressions are listed. ** including some families and genera.

stomach contents by selecting fresh otolith samples for measurements (Fig. 1).

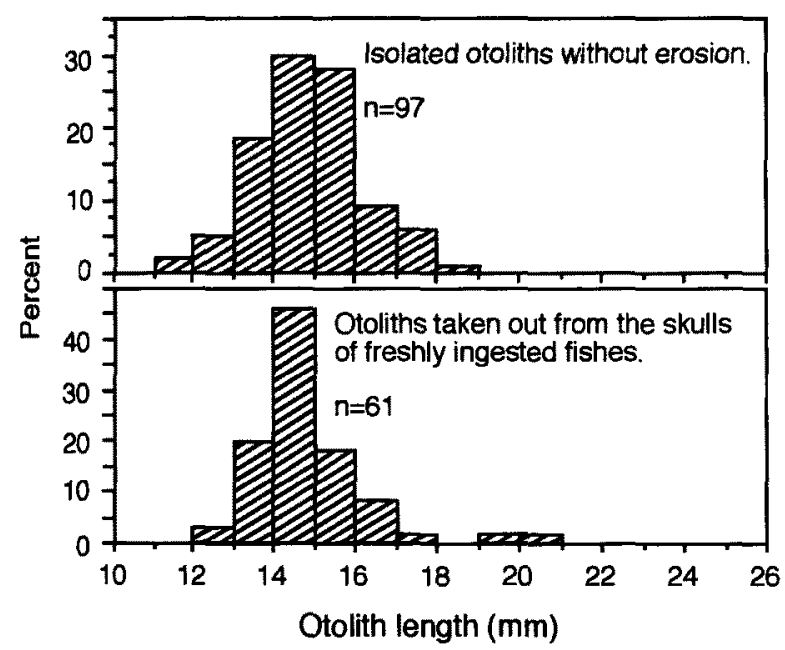

Fig. 1 Otolith length of Coryphaenoides longifilis, in the stomach contents of Baird's beaked whales in the western North Pacific. The mean of two groups are not significantly different ( $t$-test, $\mathrm{p}=0.93$ ). (Ohizumi et. al. unpubl.)

\section{ENERGY DENSITY OF PREY}

Accurate energy density is an essential factor for conversions between mass of food ingested and energy intake. The energy conversion factor is essential in estimating food consumption from the metabolic energy requirement. Some prey species show seasonal variations in fat content, which causes considerable differences in their calorie contents. Ontogenetic variation in fat and calorie content should also be considered. Mårtensson et. al. ${ }^{2)}$ investigated caloric variability in 7 Atlantic fishes. This study found that the average energy density of capelin increased about 1.5 times from spring to summer. The variation of the energy density seemed to result in minor adjustments; however, an adjustment in the energy density of approximately $-10 \%$ raises the estimate of food consumption by Atlantic minke whales by about 300,000 $t^{3)}$.

\section{PREY SELECTIVITY}

Prey selectivity is a central concept in the feeding ecology of animals. Prey species in the stomach contents are often seasonally and locally different even in the same species of dolphin. This results in the common interpretation that dolphins are "opportunists", feeding on any potential prey, and that the prey item found most often in the stomach contents is also the most abundant prey ${ }^{3), 4)}$. The designation "opportunistic feeders" suggests that dolphins are not "specialists", but it does not explain whether dolphins show some selectivity or not. To detect prey selectivity, both the relative abundance of potential prey in the habitat as well as the relative contributions of prey in the stomach contents must be analyzed.

Dall's porpoises in the northern Sea of Japan, feed mainly on Japanese pilchard (Sardinops melanostictus) when the pilchard is abundant ${ }^{5)}$. After a drastic population decline of the pilchard, Dall's porpoises switched prey to benthic walleye pollock (Theragra

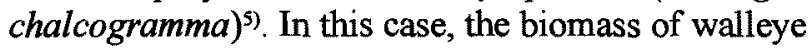
pollock does not relate to the selection, but the availability of the epipelagic pilchard relates to the selection for walleye pollock. Dall's porpoises most likely prefer epipelagic prey, and this may be correlated to foraging efficiency in habitats where there is some spatial structure in the distribution of potential preys). This example implies prey selection among toothed whales, and it is an interesting issue to consider, in light 
of behavioral ecology, the question of how whales distinguish prey species, and what is the selection criterion?

Once we understand the mechanism of prey selection, we will be able to predict how prey switching is correlated to variations in the prey population. Fisheries management based on a single-species model has many limitations; a multi-species management model is needed in the future. Such an ecosystem-based model would require information on prey selection to construct a more realistic model.

\section{FOOD CONSUMPTION AND COMPETITION BETWEEN WHALES AND FISHERIES}

The daily energy requirement (D) can be estimated from a model based on the basal metabolic rate, $\mathrm{BMR}^{ }$:

$$
\mathrm{D}=a b 70 \mathrm{~W}^{0.75}(\mathrm{kcal}) \quad \text { Eq. } 1 \text {, }
$$

where $a$ and $b$ represent assimilation efficiency and active metabolism, respectively. $W$ denotes the body weight in kilograms. The assimilation efficiency is estimated to be about $80 \%^{8}$. Active metabolism has been estimated at approximately $1.5-10$ times $\mathrm{BMR}^{7,8)}$. This wide variation is a result of different activity levels, and this factor can greatly change the results. At present, it is difficult to estimate activity levels of free-ranging animals, but about 3 times of BMR is estimated from captive odontocetes ${ }^{9}$.

Considerable consumption by cetaceans suggests potential competition between marine mammals and

Table 2. Parameters for the estimation of consumption of walleye pollock by Dall's porpoises in the northeastern Sea of Japan

\begin{tabular}{lcc}
\hline \multicolumn{1}{c}{ Parameters } & & Source \\
\hline Average body weight & $100 \mathrm{~kg}$ & $\dagger$ \\
$\begin{array}{l}\text { Population size } \\
\text { Calorific contribution of walleye }\end{array}$ & 226000 & Miyashita 28) \\
$\begin{array}{l}\text { pollock before population decline } \\
\text { of pilchards }\end{array}$ & $22 \%$ (in 1989) & Ohizumi et. al. 5) \\
$\begin{array}{l}\text { Calorific contribution of walleye } \\
\text { pollock after population decline of } \\
\text { pilchards }\end{array}$ & $63 \%$ (in 1995) & Ohizumi et. al. 5) \\
$\begin{array}{l}\text { Energy density in walleye pollock } \\
\text { Assimilation factor (a in Eq. 1) }\end{array}$ & $1.11 \mathrm{kcal} / \mathrm{g}$ & Perez 29) \\
\hline Active metabolism factor (b in Eq. 1) & 2 & $\dagger \dagger$ \\
\hline
\end{tabular}

TThis value is based on the observed data, $104.6 \pm 23.2 \mathrm{~kg}, \mathrm{n}=106$, in the North Pacific (Ohizumi H. et. al. unpubl. data). $+\dagger 80 \%$ assimilation efficiency. +† This value provides identical (about $96 \%$ ) result of the energy requirement estimation by the regression obtained from terrestrial camivorous mammals (Farlow ${ }^{30}$ ) eq.4), and also provides relatively lower (about $81 \%$ ) energy requirement of captive odontocetes (Innes et. al. ${ }^{31)}$ eq. 22) with energy conversion factor 1.11 $\mathrm{kca} V_{\mathrm{g}}$.

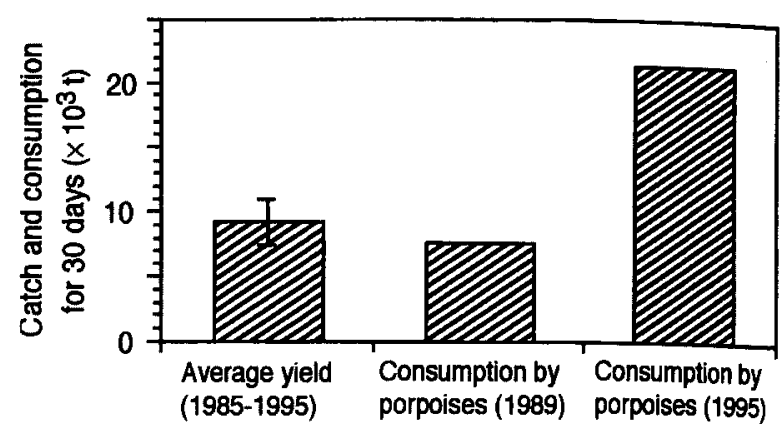

Fig.2 Estimated consumption of walleye pollock by Dall's porpoises in the Sea of Japan and the average yield by fisheries along the coast of Sea of Japan, Hokkaido. The error bar shows standard deviation. Drastic increase of consumption by porpoises reflects the prey switching after population decline of Japanese pilchard.

fisheries ${ }^{10)}$, but few examples have been documented for toothed whales. In Japanese waters, direct competition with odontocetes may occur in coastal areas.

Dall's porpoises migrate from the southern Sea of Japan to western Hokkaido in early summer, then spread out around Hokkaido. Assuming the parameters listed in Table 2, the estimated 30-day consumption of walleye pollock by Dall's porpoises in the Sea of Japan off Hokkaido ranges from $7436 \mathrm{t}$ to $21295 \mathrm{t}$ before and after the population decline of Japanese pilchards. Although this is a rough estimate based on a limited migration period and assuming all the porpoises migrate to the area, estimated consumption is comparable to the average catch of walleye pollock in Hokkaido in a month (Fig. 2). Walleye pollock is an important commercial fish around Hokkaido, but catches have been declining. This decrease is probably due to a regime shift to warmer waters ${ }^{11}$, but the foraging pressure on pollock by Dall's porpoises, especially after the decline of Japanese pilchards, may assist this decrease.

However, even if a prey species overlaps commercial fish, we should consider whether it suggests competition or sharing in each case. If the target fish is robust enough to withstand fishing and predation by whales, there may not be competition. Japanese pilchard in the western North Pacific was an important prey item to many predators, including fisheries, when the population was abundant(6,12),13). The population declined after the end of the $1980 \mathrm{~s}$, but likely not because of overharvesting or predation; rather, the increased mortality of yearling fishes attributed to the regime shift to warmer waters ${ }^{14)}$. This suggests that abundant Japanese pilchards were robust, and that all predators, including humans, could share the food.

These two examples, the suspected competition for walleye pollock and the absence of competition for Japanese pilchard, suggest that the problem of competition in the present instance depends not only 
on the whales and fisheries, but also on the abundance and ecological responses of targets to foraging and fishing pressures.

\section{REFERENCES}

1. Tollit DJ, Steward MJ, Thompson PM, Pierce GJ, Santos MB, Hughes S. Species and size differences in the digestion of otoliths and beaks: implications for estimates of pinniped diet composition. Can. J. Fish. Aquat. Sci. 1997; 54: 105119.

2. Mårtensson, PE, Gottas ARL, Nordøy ES, Blix AS. Seasonal changes in energy density of prey of northeast Atlantic seals and whales. Mar. Mammal Sci. 1996; 12: 635-640.

3. Gaskin DE. The Ecology of Whales and Dolphins. Heinemann Educational Books. London. 1982.

4. Young DD, Cockcroft VG. Diet of common dolphins (Delphinus delphis) off the south-east coast of southern Africa: opportunism or specialization? J. Zool. 1994; 234: 41.53.

5. Ohizumi H, Kuramochi T, Amano M, Miyazaki N. Prey switching of Dall's porpoise, Phocoenoides dalli, with population decline of Japanese pilchard, Sardinops melanostictus, around Hokkaido, Japan. Mar. Ecol. Prog. Ser. 2000; 200: 265-275.

6. Kleiber M. The Fire of Life. An Introduction to Animal Energetics. R.E. Krieger Publishing Company, Malabar. 1975.

7. Lockyer C. Estimation of the energy costs of growth, maintenance and reproduction in the female minke whale, (Balaenoptera acutorostrata), from the southern hemisphere. Rep. Int. Whal. Commn. 1981; 31: 337-343.

8. Lockyer $\mathrm{C}$. Growth and energy budgets of large baleen whales from the southern hemisphere. In Mammals in the Seas. FAO Fisheries Series No. 5, vol. 3. 379-487. FAO, Rome. 1981.

9. Perez MA, McAlister WB. Estimates of food consumption by marine mammales in the eastern Bering Sea. NOAA Tech. Memo. 1993; NMFS-AFSC-14.

10. Trites AW, Christensen V, Pauly D. Competition between fisheries and marine mammals for prey and primary production in the Pacific Ocean. J. NW. Atl. Fish. Sci. 1997; 22: 173-187.

11. Natsume M. Long-term fluctuations in landing of walleye pollock and arabesque greenling off the southern coast of Hokkaido. Bull. Japan. Soc. Fish. Oceanog. 1997; 61 : 8384. (in Japanese)

12. Kasamatsu F, Tanaka $S$. Annual changes in prey species of minke whales taken off Japan 1948-87. Nippon Suisan Gakkaishi. 1992; 58: 637-651.

13. Wada T, Honda $S$. Changes in stomach contents of pomfret, Brama japonica, with fluctuation in population size of Japanese sardine. Bull. Hokkaido Natl. Fish. Res. Inst. 1992; 56: $71-74$.

14. Noto M, Yasuda I. Population decline of the Japanese sardine, Sardinops melanostictus, in relation to sea surface temperature in the Kuroshio Extension. Can. J. Fish. Aquat.
Sci. 1999; 56: 973-983.

15. Ohe F. Marine Fish-otoliths of Japan. Special volume of bulletin (earth science) the senior high school attached to the Aichi Univ. of education. 1985.

16. Smale MJ, Watson G, Hecht T. Otolith Atlas of South African Marine Fishes. Ichthyological Monographs of the ЛB Smith Institute of Ichthyology, No.1. JLB Smith Institute of Ichthyology, Grahamstown. 1995.

17. Rivaton J, Bourret P. Otoliths of the Indo-Pacific Fishes. Institut de Recherché pour le Développement, Noumea. 1999.

18. Harvey JT, Loughlin TR, Perez MA, Oxman DS. Relationship between fish size and otolith length for 63 species of fishes from the eastern North Pacific Ocean. NOAA Tech. Rep. 2000; NMFS 150.

19. Ohizumi H, Watanabe H, Moku M, Kawahara S. A guide for otoliths of myctophid fishes off Japan. CD-ROM version 1.0J. National Research Institute of Far Seas Fisheries. Shimizu, Japan. 2001. (in Japanese)

20. Hotta H. Comparative Study of the Axial Skeleton of Japanese Teleostei. Tohoku Regional Fisheries Research Laboratory. 1961.

21. Takahashi Y. Study for the identification of species based on the vertebral column of teleostei in the Inland Sea and its adjacent waters. Bull. Naikai Reg. Fish. Res. Lab. 1962; 16: 1-197.

22. Tatara $K$, Yamagchi $Y$, Hayahsi $T$. Study for the restoration of length and weight of prey fishes, found in the stomachs of predators, by graphic estimation using column length of fish vertebrae. Bull. Naikai Reg. Fish. Res. Lab. 1962; 16: 199-228.

23. Watt J. Pierce GJ, Boyle PR. Guide to the Identification of North Sea Fish using Premaxillae and Vertebrae. ICES Cooperative Research Report 220. ICES, Copenhagen. 1997.

24. Hotta $\mathrm{H}$. Identification of squids and cattle fish in the adjacent waters of Japan, using the characteristics of beaks. Bull. Seikai Reg. Fish. Res. Lab. 1973; 43: 133-147.

25. Wolff GA. Identification and estimation of size from the beaks of 18 species of cephalopods from the Pacific Ocean. NOAA Tech. Rep. 1984; NMFS 17.

26. Clarke MR. A Handbook for the Identification of Cephalopod Beaks. Clarendon, Oxford. 1986.

27. Kubodera T, Ohizumi $H$. Manual for the Identification of Cephalopod Beaks in the Northwest Pacific. CD-ROM Version 1.0J. National Research Institute of Far Seas Fisheries. Shimizu, Japan. 2001. (In Japanese)

28. Miyashita T. Stocks and abundance of Dall's porpoises in the Okhotsk Sea and adjacent waters. Document submitted to IWC scientific committee. SC/43/SM7. 1991.

29. Perez MA. Calorimetry measurements of energy value of some Alaskan fishes and squids. NOAA Tech. Memo. 1994; NMFS-AFSC-32.

30. Farlow JO A consideration of the trophic dynamics of a late Cretaceous large-dinosaur community (Oldman formation). Ecology. 1976; 57: 841-857.

31. Innes S, Lavigne DM, Earle WM, Kovacs KM. Feeding rates of seals and whales. J. Anim. Ecol. 1987; 56: 115-130. 